\title{
Responses of an herbaceous community to wild boar (Sus scrofa coreanus Heude) disturbance in a Quercus mongolica forest at Mt. Jeombong, Korea
}

\author{
Doo Yong Lyang and Kyu Song Lee* \\ Department of Biology, Gangneung-Wonju National University, Gangneung 210-702, Korea
}

This research identified a disturbance regime caused by wild boar in a mature Quercus mongolica forest and analyzed the impact of this disturbance on the structure and distribution of herbaceous plants in Mt. Jeombong, Korea. We demonstrate that disturbance by wild boar was most frequent from winter to early spring, but also occurred year round. Areas which were frequently disturbed by wild boar included the mountain ridge, the mild slope on the north face, and sites with high concentration of Erythronium japonicum. The disturbance cycle by the wild boar in this region was estimated at approximately 2.8 years. The wild boar's reduced the community's species diversity and herbaceous coverage, and increased its evenness. This disturbance reduced the coverage of spring ephemeral; Veratrum nigrum var. ussuriense, Symplocarpus niponnicus, Anemone koraiensis and Corydalis turtschaninovii were particularly sensitive. In addition, summer green herbaceous plants such as Astilbe chinensis, Ainsliaea acerifolia, Meehania urticifolia, and Pimpinella brachycarpa were sensitive to the wild boar's. It was found that wild boar ate E. japonicum most selectively of all plants in this investigation area. In conclusion, together with micro-topography, wind, formation of gaps of a forest and rearrangement of litter layer, wild boar's disturbance is an important factor influencing the dynamic changes of an herbaceous community in a mature temperate hardwood forest.

Key words: disturbance, Erythronium japonicum, Quercus mongolica forest, spatial heterogeneity, spring ephemeral, wild boar

\section{INTRODUCTION}

Disturbance functions as an essential element for increasing temporal and spatial heterogeneity and maintaining species diversity in the ecosystem (Lee and Cho 1999, Tierney and Cushman 2006). Herbaceous plants distributed in a forest show the quickest response to micro-environmental differences caused by disturbance in the ecosystem, and disturbance exerts a direct influence on the growth and biomass of these plants (Kim 1997).

In Korea, tigers and leopards are extinct due to population growth and industrialization following Japanese imperialistic rule, and bears, goats and musk deer dis- tributed in some areas are now facing extinction (Kim et al. 1998). The wild boar (Sus scrofa coreanus) is a species which belongs to the Sus scrofa family of Artiodactyla and is a large mammal common in South Korea. Wild boars are prolific and have strong recuperative powers allowing them to survive hunting and natural predators (Choi and Choi 2008). Recently, it was revealed that wild animals are quickly proliferating due to improved environmental preservation and regulation of poaching; and as a result, damage by wild boar is gradually increasing in the areas surrounding national parks (Yoon 2007). Moody and (cc) This is an Open Access article distributed under the terms of the Creative Commons Attribution Non-Commercial License (http://creativecommons.org/licenses/by-nc/3.0/) which permits unrestricted non-commercial use, distribution, and reproduction in any medium, provided the original work is properly cited.
Received 5 March 2010, Accepted 2 April 2010

${ }^{*}$ Corresponding Author

E-mail: leeks84@gwnu.ac.kr

Tel: +82-33-640-2311 
Jones (2000) found that in Santa Cruz California the soil's $\mathrm{pH}$, soil moisture content, nitrate and carbon content are more closely related to the distance of the center of trees than by the wild boar's disturbance. Groot Buinderink and Hazebroek (1996) discovered that in the Netherlands' deciduous coniferous forests wild boar did not affect the soil's $\mathrm{pH}$, organic content and nitrate content, or the growth of plant. Gómez and Hódar (2008) found that in Spain wild boar's foraging reduces the survival rate of seeds in a forest. Tierney and Cushman (2006) demonstrated that when California's grassland was disturbed by wild boar, species richness and coverage of the introduced species increased rapidly in the earlier stage, but those of endemic species increased gradually in the later stage. Milton et al. (1997) discovered that in the central Germany small-scale ground disturbance reduces species richness and diversity of plants. From an analysis of stomach contents of wild boar captured in the island Sardinia of Italy, Pinna et al. (2007) identified its primary diet consisted of acorn and centipede. In western Eurasia the population density of wild boar is more closely related to the climate than to its natural predator, the wolf; this suggests that the distribution and population density of wild boar could be changed by climate warming (Melis et al. 2006). Further, it is known that wild boar's territorial range is proportional to its weight (Kim et al. 1998).

In the forest ecosystem the ground disturbance by the wild boar's foraging activity forms pits, mounds, and plains. It also changes micro-environments including the thickness and amount of fallen leaves, soil temperature, and water content (Lee and Cho 1999, Pinna et al. 2007). The changes of micro-environments on the ground will cause differences of the dominance among plants which thrive in those environments. It is predicted that the different temporal and spatial changes on the herbaceous vegetation are triggered by many factors, including the structure of vegetation before disturbance, the period of wild boar's disturbance, the position of slope, and wild boar's population movement. The following must be investigated to understand the how increasing wild boar populations will effect Korea's forest ecosystem: (1) wild boar's behavior, (2) the environmental condition of wild boar's habitat, (3) wild boar's diet, and (4) the interaction of wild boar and other living things.

In order to understand the influence of the wild boar on the herbaceous layers in the forest ecosystem, this research identified a disturbance regime by wild boar that changes temporally and spatially, influences of wild boar's disturbance to the micro-environment, and the response of the herbaceous community in a mature Quer- cus mongolica forest at Mt. Jeombong.

\section{MATERIALS AND METHODS}

\section{Description of the study site}

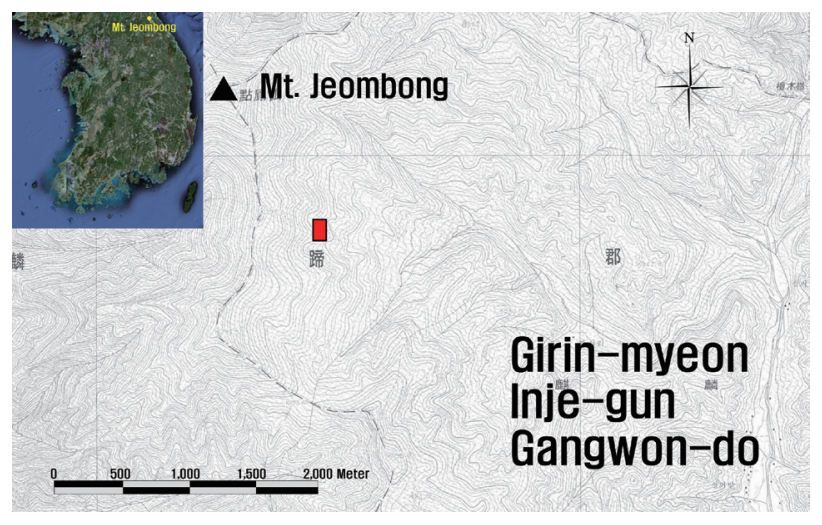

Fig. 1. Layout of the permanent plot (square) established in a Quercus mongolica community for this study in Mt. Jeombong, Korea.

Mt. Jeombong is located at the southern end of Soraksan National Park, the administrative boundary line of Jindong-ri and Gwidoon-ri of Girin-myeon, and Oga-ri of Seo-myeon, of Inje-gun, Gangwon-do (E 128 $25^{\circ}-30^{\prime}$, N $38^{\circ} 0^{\prime}-5^{\prime}$ ) (Fig. 1). In $1982 \mathrm{Mt}$. Jeombong was designated as part of the Sorak Biosphere Reserve by the UNESCO' Man and Biosphere Project together with Mt. Sorak. In addition, Mt. Jeombong is designated as a reserved forest for the protection of genetic resources (Kim et al. 1998). In Mt. Jeombong a mature Q. mongolica forest is distributed widely and long-term ecological monitoring has been conducted since 2004 (Hong 2005). The investigation site is located at a permanent plot for the longterm ecological research of mature $Q$. mongolica forest. The GPS position of investigation plot is N $38^{\circ} 02^{\prime} 10.3^{\prime \prime}$ and $\mathrm{E} 128^{\circ} 26^{\prime} 11.1^{\prime \prime}$. It is located from 1,000 to $1,100 \mathrm{me}-$ ters above sea level. Its slope ranges from $14^{\circ}$ to $38^{\circ}$ and consists of the south-slope, the mountain ridge and the north-slope aspect.

\section{Methods}

We extended the permanent plot (1 ha) previously built for the long-term ecological monitoring in 2004 and installed a permanent plot for the investigation which has a total area of $1.6 \mathrm{ha}$. The permanent plot is divided into sub-quadrat $(20 \mathrm{~m} \times 20 \mathrm{~m})$ and micro-quadrat (10 $\mathrm{m} \times 10 \mathrm{~m}$ ). In order to characterize the wild boar's in the permanent plot, we investigated the size and depth of 
disturbance traces by wild boar at 7 times (April 20, June 12, August 31 and October 30 in 2008; April 9, June 11 and August 28 in 2009) and prepared a disturbance map using CAD (AutoCAD 2008; Autodesk, Inc., San Rafael, CA, USA). We calculated the distribution by size of disturbance traces and the area of disturbance using the map. Proportion (\%) of disturbed area by wild boar according to the micro-topography was calculated by comparing the percentage of disturbed area to the south-facing slope, the mountain ridge, the north-facing slope and total plot areas. To compare local environmental factors among micro-topographic sites formed by wild boar, we divided the sites into pit, mound, and flat, corresponding to the south-facing slope, the mountain ridge and the north-facing slope respectively. We measured the temperature of the surface and $-5 \mathrm{~cm}$ underground, the thickness and coverage of the litter layer, and soil moisture content based on the wet soil on April 22 in 2009. The litter index was calculated by multiplying their thickness to coverage of the litter layer. To understand the influence of the wild boar's disturbance on the herbaceous community, we identified a non-disturbed site to serve as a control (CON), an old wild boar disturbed site (OW) and a new wild boar disturbed site (NW). CON refers to an established quadrat which was not disturbed on June 27 in 2008. OW stands for a site disturbed before April 2008. NW refers to a site disturbed between April and June in 2008. We investigated the herbaceous community in each of established quadrats in 5 times (June 27 and September 3 in 2008; May 18, June 27 and September 3 in 2009). We calculated Shannon-Weaver's diversity index ( $\left.H^{\prime}\right)$, and Pielou's (1969) evenness index (J') and species richness by using vegetation data obtained from the field. The program SYSTAT 12.0 (SPSS Inc., Chicago, IL, USA) was used for correlation analysis and analysis of variance. The Turkey test was used for the post-hoc test of the analysis of variance. We analyzed detrended corre- spondence analysis (DCA) ordination by using CANOCO 4.0 (GLW-Cp.; Wageningen, The Netherlands). We prepared a spatial distribution map with GS+ (Gamma Design SoftWare, Plainwell, MI, USA).

\section{RESULTS}

\section{Wild boar's disturbance regime}

The season in which disturbance by wild boars was most severe in the investigation site was the period from late autumn to early spring when they have enough food on the ground. While disturbances occurred at all seasons of the year, the frequency of disturbance varied from season to season. In addition, the mountain ridge and the north-facing slope were disturbed more frequently than the south-facing slope area (Table 1). Fig. 2 indicates the total annual disturbed area between April 2008 and April 2009. Fig. 3 shows the disturbed area from October 2008 to April 2009. The ratio of disturbed area in the southfacing slope, the mountain ridge, the north-facing slope and the whole plot following this one-year investigation was $23.7 \%, 50.1 \%, 35.9 \%$ and $35.7 \%$, respectively (Fig. 4 ). The disturbance cycle by wild boar in the south-facing slope, the mountain ridge, the north-facing slope and the whole plot was 3.7 years, 2.0 years, 2.8 years and 2.8 years, respectively, based on the above ratio. This calculation did not consider overlapping disturbances to one area. When overlapping disturbances are considered, the wild boar's disturbance occurs more frequently (Fig. 4). If we consider overlapping disturbances, the area ratio of disturbed area in the south-facing slope, the mountain ridge, the north-facing slope and the whole plot will be $27.3 \%, 65.3 \%, 45.9 \%$ and $45.1 \%$, respectively (Fig. 4). Fig. 5 shows the changes of the disturbed area ratio in the investigated site from 2004 to 2009. The cycle of wild boar's

Table 1. Proportion (\%) of disturbed area by wild boar according to the micro-topographies in a 1.6 ha plot from April 2008 to June 2009 at Mt. Jeombong

\begin{tabular}{lcccr}
\hline Investigation period & South-facing slopes & Ridge & North-facing slopes & Total \\
\hline Before Apr 2008 & 9.45 & 37.08 & 24.31 & 23.10 \\
Apr 2008-Jun 2008 & 4.91 & 7.89 & 8.16 & 7.21 \\
Jun 2008-Aug 2008 & 4.07 & 16.69 & 11.33 & 10.61 \\
Aug 2008-Oct 2008 & 0.81 & 4.24 & 6.58 & 4.56 \\
Oct 2008-Apr 2009 & 17.34 & 36.47 & 19.59 & 22.77 \\
Apr 2009-Jun 2009 & 5.91 & 18.86 & 14.04 & 12.89 \\
Jun 2009-Aug 2009 & 4.18 & 10.53 & 6.70 & 6.87 \\
\hline
\end{tabular}




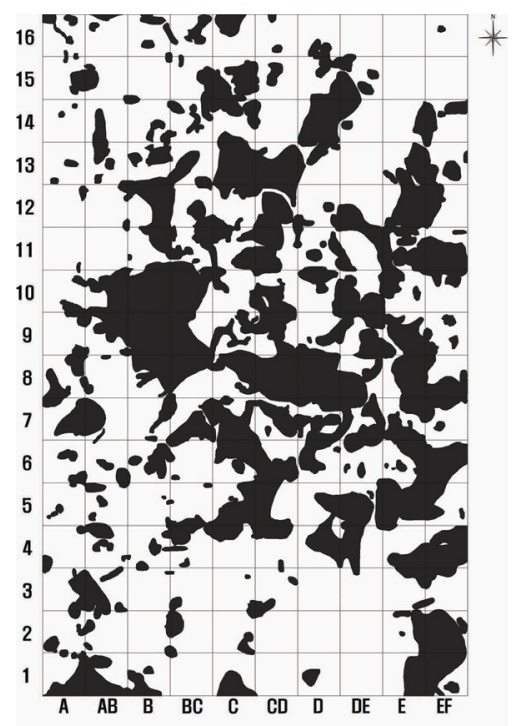

Fig. 2. Distribution of traces by wild boars' disturbance in 1.6 ha plot from April in 2008 to April 2009.

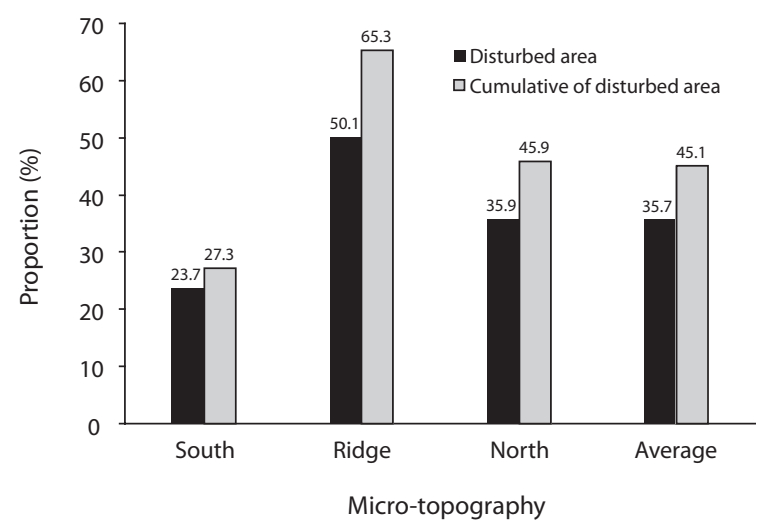

Fig. 4. Proportion (\%) of the annual and cumulative disturbed area including overlapping disturbances by wild boar in the south-facing slope, ridge, north-facing slope and whole plot area in a 1.6 ha plot from April in 2008 to April in 2009.

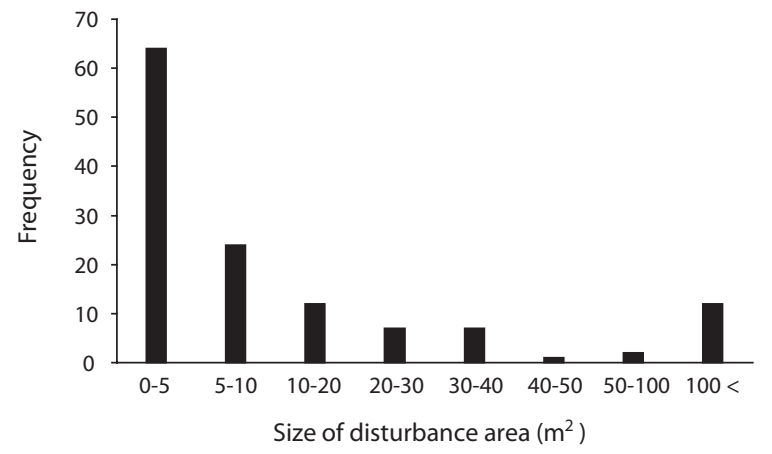

Fig. 6. Frequency of the disturbance traces binned according to the size of the disturbed area from April in 2008 to April in 2009.

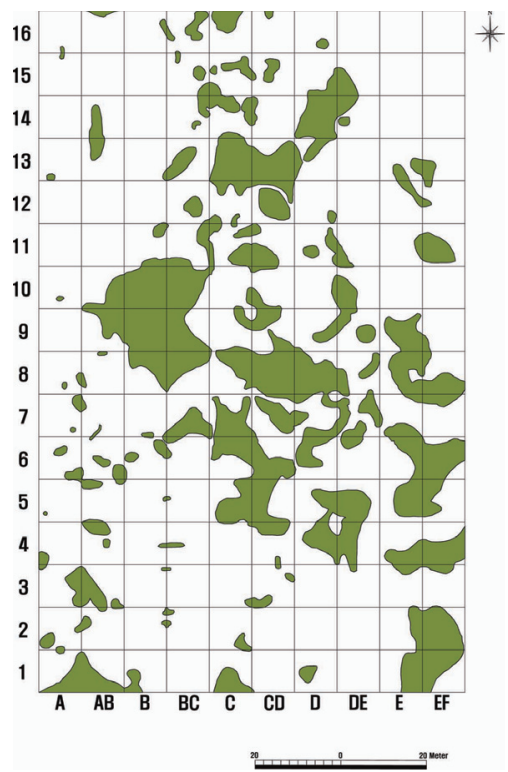

Fig. 3. Distribution of traces by wild boars' disturbance in 1.6 ha plot from October in 2008 to April in 2009.

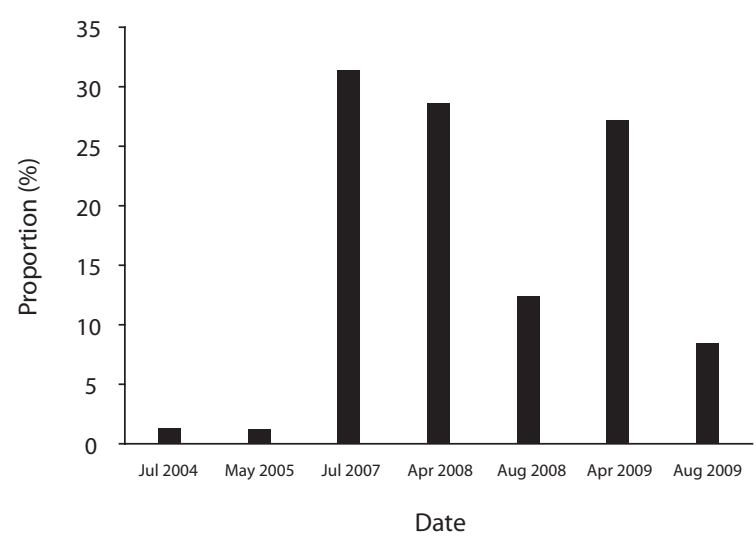

Fig. 5. Changes of the proportion (\%) of disturbed area by wild boar in 1.0 ha plot for the long-term ecological research from July 2004 to August 2009 at Mt. Jeombong.

disturbance might be longer than 2.8 years because wild boar's activity in this area remarkably increased from 2007.

Fig. 6 indicates frequency of the size (area) class disturbed by wild boar for one year from April 2008 to April 2009. The most frequent size class which shows over 60 times was $0-5 \mathrm{~m}^{2}$. The second most frequent size class was $5-10 \mathrm{~m}^{2}$. The size class greater than $100 \mathrm{~m}^{2}$ showed more frequency than 10 times (Fig. 6). The largest disturbed areas during the periods from April to June in 2008, June to August in 2008, August to October in 2008, October in 2008 to April in 2009, April to June in 2009 and June to August in 2009 were $89 \mathrm{~m}^{2}, 183 \mathrm{~m}^{2}, 147 \mathrm{~m}^{2}, 564 \mathrm{~m}^{2}$, 
$412 \mathrm{~m}^{2}$, and $160 \mathrm{~m}^{2}$, respectively. The period from October in 2008 to April in 2009 showed the largest disturbed area of the above periods. If we consider overlapping disturbances, the largest size of disturbed area during investigation period was 2,258 $\mathrm{m}^{2}$ (Lyang 2010).

\section{Comparison of environmental factors among micro-topographies formed by wild boar}

Table 2. Comparison of the micro-environmental factors (mean \pm standard deviation) on the ground layer among pit, flat and mound areas, micro-topographies created by wild boar in Mt. Jeombong $(N=12, P<0.05)$

\begin{tabular}{|c|c|c|c|c|}
\hline Factors & & Pit & Mound & Flat \\
\hline \multirow{2}{*}{ Soil temperature $\left({ }^{\circ} \mathrm{C}\right)$} & $0 \mathrm{~cm}$ & $13.9 \pm 1.7^{\mathrm{a}}$ & $15.3 \pm 1.2^{\mathrm{a}}$ & $14.1 \pm 2.0^{\mathrm{a}}$ \\
\hline & $-5 \mathrm{~cm}$ & $11.4 \pm 2.5^{\mathrm{a}}$ & $12.6 \pm 1.9^{\mathrm{a}}$ & $12.3 \pm 2.1^{\mathrm{a}}$ \\
\hline Litter depth (cm) & & $3.1 \pm 9.5^{\mathrm{a}}$ & $1.6 \pm 6.5^{\mathrm{b}}$ & $2.4 \pm 12.5^{\mathrm{ab}}$ \\
\hline $\begin{array}{l}\text { Coverage (\%) } \\
\text { of litter layer }\end{array}$ & & $64.2 \pm 16.6^{\mathrm{a}}$ & $28.0 \pm 14.2^{\mathrm{b}}$ & $67.9 \pm 30.6^{\mathrm{a}}$ \\
\hline Litter index & & $232.5 \pm 183.5^{\mathrm{a}}$ & $57.1 \pm 72.4^{\mathrm{b}}$ & $164.4 \pm 114.3^{\mathrm{ab}}$ \\
\hline $\begin{array}{l}\text { Moisture } \\
\text { content (\%) }\end{array}$ & & $39.5 \pm 6.2^{\mathrm{a}}$ & $36.4 \pm 4.5^{\mathrm{a}}$ & $38.4 \pm 3.2^{\mathrm{a}}$ \\
\hline
\end{tabular}

Ground soil temperature pit, flat, and mound, the micro-topographies generated by wild boar, $13.9^{\circ} \mathrm{C}, 14.1^{\circ} \mathrm{C}$, and $15.3^{\circ} \mathrm{C}$. The temperatures $-5 \mathrm{~cm}$ underground were $11.4^{\circ} \mathrm{C}, 12.3^{\circ} \mathrm{C}$, and $12.6^{\circ} \mathrm{C}$, respectively; this was similar to that of the temperature of the surface (Table 2). The soil moisture content of pit, flat and mound were $39.5 \%$, $38.4 \%$ and $36.4 \%$, respectively (Table 2 ). The litter depth on pit, flat and mound were $3.1 \mathrm{~cm}, 2.4 \mathrm{~cm}$, and $1.6 \mathrm{~cm}$, respectively. The coverage of litter layer on pit, flat and mound were $64 \%, 68 \%$ and $28 \%$. Here, it was notable that coverage of litter layer on mound was significantly lower than the other micro topographies. The litter indices on pit, flat and mound were 233,164 , and 57 , respectively. The litter index on pit was significantly different compared to mound (Table 2).

\section{Responses of herbaceous community by wild boar}

The species richness and sum of coverage of each species at the initial time of study (June 2008) had a tendency to become decrease in the order of CON, OW and NW.

Table 3. Comparison of the structural characteristics (mean \pm standard deviation) of the herbaceous community in each investigation season $(P<0.05)$

\begin{tabular}{|c|c|c|c|c|}
\hline Structural characteristics & Investigation season & $\operatorname{CON}(N=26)$ & OW $(N=24)$ & NW $(N=24)$ \\
\hline \multirow{5}{*}{ Species richness (SR) } & Jun 2008 & $10.2 \pm 2.7^{\mathrm{a}}$ & $9.6 \pm 3.2^{\mathrm{a}}$ & $7.3 \pm 2.6^{\mathrm{b}}$ \\
\hline & Sep 2008 & $7.7 \pm 3.1^{\mathrm{a}}$ & $7.3 \pm 3.5^{\mathrm{a}}$ & $6.0 \pm 2.8^{\mathrm{a}}$ \\
\hline & May 2009 & $12.2 \pm 3.1^{\mathrm{a}}$ & $11.2 \pm 3.1^{\mathrm{ab}}$ & $9.4 \pm 2.9^{b}$ \\
\hline & Jun 2009 & $10.7 \pm 3.7^{\mathrm{a}}$ & $10.0 \pm 2.8^{\mathrm{ab}}$ & $8.3 \pm 2.8^{\mathrm{b}}$ \\
\hline & Sep 2009 & $7.5 \pm 3.5^{\mathrm{a}}$ & $7.0 \pm 3.1^{\mathrm{a}}$ & $6.1 \pm 2.6^{\mathrm{a}}$ \\
\hline \multirow{5}{*}{$\begin{array}{l}\text { Sum of coverage of the each } \\
\text { species }(\%)\end{array}$} & Jun 2008 & $99.2 \pm 26.1^{\mathrm{a}}$ & $59.8 \pm 33.9^{\mathrm{b}}$ & $15.7 \pm 13.1^{\mathrm{c}}$ \\
\hline & Sep 2008 & $117.6 \pm 34.5^{\mathrm{a}}$ & $89.2 \pm 38.0^{\mathrm{b}}$ & $57.8 \pm 33.0^{\mathrm{c}}$ \\
\hline & May 2009 & $115.0 \pm 37.5^{\mathrm{a}}$ & $60.3 \pm 28.9^{\mathrm{b}}$ & $33.2 \pm 19.1^{\mathrm{c}}$ \\
\hline & Jun 2009 & $118.7 \pm 28.0^{\mathrm{a}}$ & $81.4 \pm 42.1^{\mathrm{b}}$ & $38.3 \pm 30.0^{\mathrm{c}}$ \\
\hline & Sep 2009 & $74.6 \pm 32.8^{\mathrm{a}}$ & $53.6 \pm 28.7^{\mathrm{b}}$ & $38.5 \pm 25.8^{\mathrm{b}}$ \\
\hline \multirow{5}{*}{ Diversity index (H') } & Jun 2008 & $1.42 \pm 0.38^{\mathrm{a}}$ & $1.35 \pm 0.46^{\mathrm{a}}$ & $1.48 \pm 0.38^{\mathrm{a}}$ \\
\hline & Sep 2008 & $1.65 \pm 0.42^{\mathrm{a}}$ & $1.58 \pm 0.50^{\mathrm{a}}$ & $1.30 \pm 0.57^{\mathrm{a}}$ \\
\hline & May 2009 & $1.89 \pm 0.33^{\mathrm{a}}$ & $1.88 \pm 0.30^{\mathrm{a}}$ & $1.68 \pm 0.33^{\mathrm{a}}$ \\
\hline & Jun 2009 & $1.68 \pm 0.40^{\mathrm{a}}$ & $1.68 \pm 0.29^{\mathrm{a}}$ & $1.47 \pm 0.43^{\mathrm{a}}$ \\
\hline & Sep 2009 & $1.40 \pm 0.45^{\mathrm{a}}$ & $1.35 \pm 0.46^{\mathrm{a}}$ & $1.34 \pm 0.43^{\mathrm{a}}$ \\
\hline \multirow{5}{*}{ Evenness index (J') } & Jun 2008 & $0.62 \pm 0.14^{\mathrm{a}}$ & $0.60 \pm 0.16^{\mathrm{a}}$ & $0.78 \pm 0.15^{\mathrm{b}}$ \\
\hline & Sep 2008 & $0.84 \pm 0.11^{\mathrm{a}}$ & $0.84 \pm 0.10^{\mathrm{a}}$ & $0.75 \pm 0.25^{\mathrm{a}}$ \\
\hline & May 2009 & $1.34 \pm 0.24^{\mathrm{a}}$ & $1.28 \pm 0.15^{\mathrm{a}}$ & $1.33 \pm 0.18^{\mathrm{a}}$ \\
\hline & Jun 2009 & $0.72 \pm 0.11^{\mathrm{a}}$ & $0.75 \pm 0.08^{\mathrm{a}}$ & $0.72 \pm 0.11^{\mathrm{a}}$ \\
\hline & Sep 2009 & $0.72 \pm 0.13^{\mathrm{a}}$ & $0.75 \pm 0.14^{\mathrm{a}}$ & $0.77 \pm 0.14^{\mathrm{a}}$ \\
\hline \multirow{5}{*}{ Dominance Index (C) } & Jun 2008 & $0.36 \pm 0.16^{\mathrm{a}}$ & $0.40 \pm 0.18^{\mathrm{a}}$ & $0.32 \pm 0.14^{\mathrm{a}}$ \\
\hline & Sep 2008 & $0.24 \pm 0.11^{\mathrm{a}}$ & $0.26 \pm 0.14^{\mathrm{a}}$ & $0.35 \pm 0.24^{\mathrm{a}}$ \\
\hline & May 2009 & $0.21 \pm 0.10^{\mathrm{a}}$ & $0.21 \pm 0.07^{\mathrm{a}}$ & $0.26 \pm 0.10^{\mathrm{a}}$ \\
\hline & Jun 2009 & $0.28 \pm 0.13^{\mathrm{a}}$ & $0.25 \pm 0.09^{a}$ & $0.32 \pm 0.16^{\mathrm{a}}$ \\
\hline & Sep 2009 & $0.35 \pm 0.15^{\mathrm{a}}$ & $0.36 \pm 0.15^{\mathrm{a}}$ & $0.34 \pm 0.15^{\mathrm{a}}$ \\
\hline
\end{tabular}

CON, control; OW, old wild boar disturbed site; NW, new wild boar disturbed site. 
Evenness had decreased in the order of NW, CON and OW. The sum of coverage of the each species becomes remarkably decreased in the order of CON, OW and NW. Species richness of NW was significantly decreased compared to CON and OW. Evenness index of NW was significantly higher compared to CON and OW. There were no significant differences in species diversity $\left(\mathrm{H}^{\prime}\right)$ or dominance index (C) among CON, OW and NW. There was no significant difference in the structural characteristics of communities between CON and OW except sum of coverage of the each species. These results suggest that new disturbances by wild boar have affected the sum of coverage of each species, species richness and evenness index of the herbaceous community. However, the structural characteristics of the NW community were similar to those of the OW community according to the time elapsed after disturbance (Table 3).

New disturbance by wild boar occurred in all locations from June 2008 to September 2009. The newly disturbed areas had a tendency decrease in the order of NW, OW

Table 4. Comparison of the newly disturbed area (\%, mean \pm standard deviation) by wild boar during each investigation period (Jun 2008-Sep 2009) $(P<0.05)$

\begin{tabular}{lccc}
\hline $\begin{array}{c}\text { Investigation } \\
\text { period }\end{array}$ & CON $(N=26)$ & OW $(N=24)$ & NW $(N=24)$ \\
\hline $\begin{array}{l}\text { Jun 2008-May } \\
\text { 2009 }\end{array}$ & $12.5 \pm 21.4^{\mathrm{a}}$ & $19.4 \pm 26.0^{\mathrm{a}}$ & $29.4 \pm 34.8^{\mathrm{a}}$ \\
$\begin{array}{l}\text { May 2009-Jun } \\
\text { 2009 }\end{array}$ & $12.7 \pm 16.1^{\mathrm{a}}$ & $16.9 \pm 19.3^{\mathrm{a}}$ & $19.4 \pm 23.5^{\mathrm{a}}$ \\
$\begin{array}{l}\text { Jun 2009-Sep } \\
\text { 2009 }\end{array}$ & $38.2 \pm 27.3^{\mathrm{a}}$ & $43.3 \pm 28.5^{\mathrm{a}}$ & $47.4 \pm 32.8^{\mathrm{a}}$ \\
\hline
\end{tabular}

CON, control; OW, old wild boar disturbed site; NW, new wild boar disturbed site. and CON. However, there was no significant difference among treatments (Table 4).

To comprehensively understand the influence of wild boar's disturbance on the structural characteristics of the herbaceous community, we conducted a DCA ordination based on the data matrix of 12 characteristics of community obtained from three measurements on June 27 in 2008. As a result, an eigenvalues of axis 1 and 2 were $0.31(82 \%$ of whole variance) and $0.039(10 \%$ of whole variance), respectively. The quadrats belonging to NW had a tendency to locate on the right side and those belong to CON on the left side of DCA axis 1. Quadrats belong to OW and NW showed the most widely distribution according to DCA axis 1. Quadrats belong to CON showed the widest distribution according to DCA axis 2 . The quadrats located in the north-facing slope areas had a tendency to distribute on the upper side of DCA axis 2 (Fig. 7). Correlation coefficients between the 12 structural characteristics of the herbaceous community and stand scores of DCA axis 1 and 2 were put together in Table 5. The structural characteristics of herbaceous community demonstrating a negative correlation with stand scores on DCA axis 1 were the species richness, height and coverage of herb layer, sum of coverage of the each species and spring ephemeral species, and depth and coverage of litter layer. The structural characteristics of the herbaceous community indicating a positive correlation with stand scores on DCA axis 1 were the evenness, depth of disturbed site and areas which were newly disturbed during the investigation period. The characteristics of the community indicating a close negative correlation with stand scores on axis 2 were the species richness, cover-

Table 5. Correlation coefficients between the structural characteristics of the herbaceous community and stand scores of detrended correspondence analysis ordination axis 1 and 2 on June in 2008

\begin{tabular}{lcc}
\hline & \multicolumn{2}{c}{ Correlation coefficients } \\
\hline Structural characteristics & Axis 1 & Axis 2 \\
\cline { 2 - 3 } & $-0.422^{*}$ & $-0.565^{* * *}$ \\
Species richness (SR) & 0.063 & -0.118 \\
Evecies diversity index (H') & $0.432^{*}$ & 0.289 \\
Dominance index (C) & -0.131 & -0.027 \\
Height of herb layer (cm) & $-0.558^{* * *}$ & 0.087 \\
Coverage of herb layer (\%) & $-0.908^{* * *}$ & $-0.671^{* * *}$ \\
Litter depth (cm) & $-0.443^{* *}$ & 0.093 \\
Coverage of litter layer (\%) & $-0.769^{* * *}$ & -0.117 \\
Depth of disturbance (cm) & $0.727^{* * *}$ & $0.491^{* * *}$ \\
Newly disturbed area by wild boar (\%) & $0.861^{* * *}$ & 0.374 \\
Sum of the coverage of the each species (\%) & $-0.898^{* * *}$ & $-0.665^{* * *}$ \\
Sum of the coverage of the spring ephemeral species $(\%)$ & $-0.425^{*}$ & 0.353 \\
\hline
\end{tabular}

*Significant at $0.05 \%$ level, ${ }^{* *}$ significant at $0.01 \%$ level, ${ }^{* * *}$ significant at $0.001 \%$ level. 


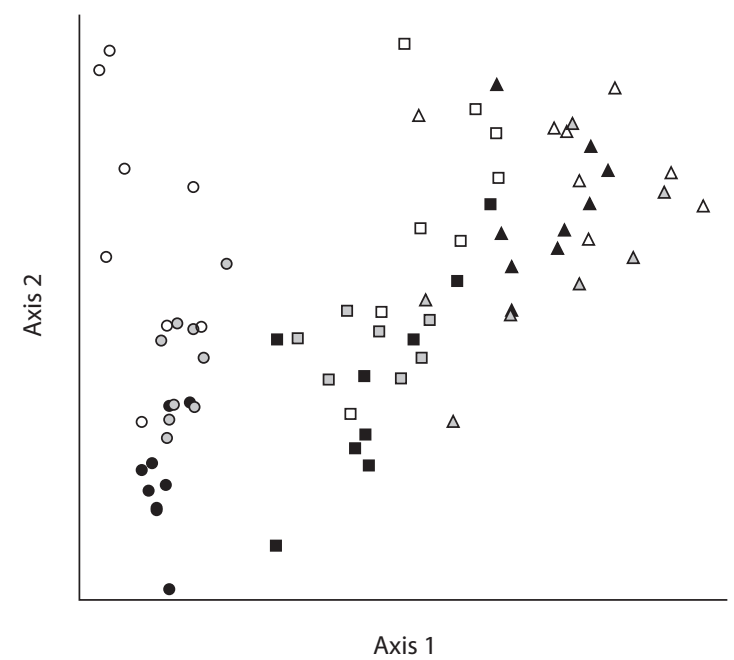

- SCON O RCON O NCON $\square$ SOW $\square$ ROW $\square$ NOW $\Delta$ SNW $\triangle$ RNW $\triangle N N W$

Fig. 7. DCA ordination of the treatments based on the structural characteristics of the herbaceous community investigated in June 2008. DCA, detrended correspondence analysis; $S$, south-facing area; $R$, ridge area; $\mathrm{N}$, north-facing area; CON, control; OW, old wild boar disturbed site; NW, new wild boar disturbed site.

age of herb layer, and the sum of coverage of herbaceous plant species. The only characteristic of the community showing a close positive correlation with these scores was the depth of disturbed site (Table 5). Therefore, we conclude that wild boar's disturbance affected most of structural characteristics of the community.

\section{Response of major herbaceous plants Early spring herbaceous plants (Spring ephemeral)}

The sum of coverage of the spring ephemeral species in CON, OW and NW in May 2009 was 45.7\%, 20.9\% and $16.7 \%$, respectively. The sum of coverage measured in OW and NW was significantly lower than CON (Fig. 8). Coverage of Veratrum nigrum var. ussuriense and Corydalis

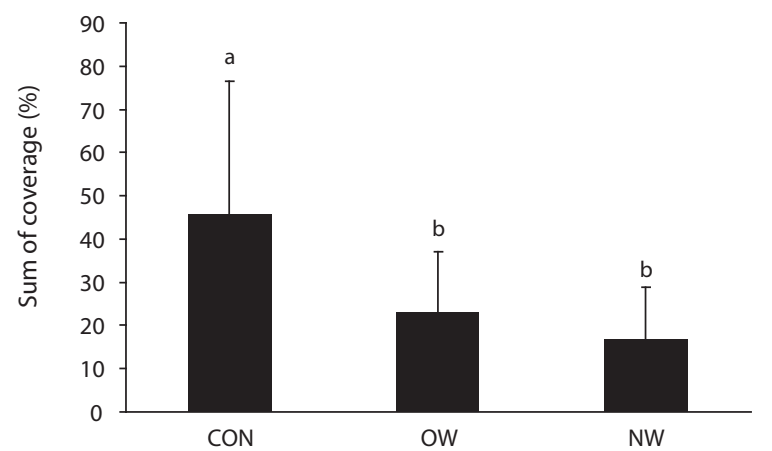

Fig. 8. Comparison of the sum of coverage $(\%$, mean \pm standard deviation) of the spring ephemeral species among treatments $(P<0.05)$. CON, control; OW, old wild boar disturbed site; NW, new wild boar disturbed site. turtschaninovii had a decreased in the order of CON, OW and NW, and NW was significantly decreased compared to CON. Coverage of Erythronium japonicum was decreased in NW and OW compared to CON, but there was no significant difference among them. Coverage of Symplocarpus niponnicus decreased in the order of CON, OW and NW, and the coverage in NW significantly decreased compared to CON. Coverage of Anemone koraiensis decreased in the order of CON, OW and NW, and the coverage in OW and NW was significantly lower than CON. Coverage of Anemone raddeana and Leontice microrhyncha was greatest in $\mathrm{CON}$ and NW, respectively, but there was no significant difference among treatments (Table 6). These results suggest that wild boar's disturbance affects the distribution and abundance of the spring ephemeral in a temperate hardwood forest.

Table 6. Comparison of the coverage ( $\%$, mean \pm standard deviation) of the each spring ephemeral species among treatments $(P<0.05)$

\begin{tabular}{lccc}
\hline \multicolumn{1}{c}{ Species } & CON $(N=26)$ & OW $(N=24)$ & NW $(N=24)$ \\
\hline Veratrum nigrum var. ussuriense & $12.0 \pm 20.4^{\mathrm{a}}$ & $4.5 \pm 9.7^{\mathrm{ab}}$ & $0.6 \pm 2.2^{\mathrm{b}}$ \\
Erythronium japonicum & $10.8 \pm 14.3^{\mathrm{a}}$ & $5.8 \pm 6.8^{\mathrm{a}}$ & $6.0 \pm 6.0^{\mathrm{a}}$ \\
Symplocarpus nipponicus & $7.9 \pm 9.2^{\mathrm{a}}$ & $4.6 \pm 4.2^{\mathrm{ab}}$ & $3.4 \pm 2.9^{\mathrm{b}}$ \\
Anemone koraiensis & $6.6 \pm 10.0^{\mathrm{a}}$ & $2.0 \pm 3.3^{\mathrm{b}}$ & $1.2 \pm 3.1^{\mathrm{b}}$ \\
Corydalis turtschaninovii & $6.2 \pm 8.4^{\mathrm{a}}$ & $4.5 \pm 7.9^{\mathrm{ab}}$ & $3.3 \pm 5.9^{\mathrm{b}}$ \\
Anemone raddeana & $1.9 \pm 3.4^{\mathrm{a}}$ & $0.6 \pm 1.4^{\mathrm{a}}$ & $0.7 \pm 1.7^{\mathrm{a}}$ \\
Anemone reflexa & $0.1 \pm 0.2^{\mathrm{a}}$ & $0.0 \pm 0.1^{\mathrm{a}}$ & $0.2 \pm 1.0^{\mathrm{a}}$ \\
Leontice microrhyncha & $0.2 \pm 1.0^{\mathrm{a}}$ & $0.8 \pm 4.1^{\mathrm{a}}$ & $1.3 \pm 6.1^{\mathrm{a}}$ \\
Total coverage of herb layer $(\%)$ & $67.7 \pm 17.2^{\mathrm{a}}$ & $37.1 \pm 16.5^{\mathrm{b}}$ & $22.8 \pm 13.7^{\mathrm{c}}$
\end{tabular}

CON, control; OW, old wild boar disturbed site; NW, new wild boar dis turbed site.

\section{Summer green herbaceous plants}

The sum of coverage of summer green herbaceous plant species during the period of investigation decreased in the order of CON, OW and NW (Table 7). In particular, there were distinct differences of coverage among dominant Astilbe chinensis, Ainsliaea acerifolia, Meehania urticifolia, and Pimpinella brachycarpa between disturbed sites and CON on June 27, 2008. However, differences of coverage among them were gradually waned due to the recovery of vegetation according to the time elapsed. The coverage of other plant species which were not presented in this research showed the some difference among treatments but there was no statistical significance (Lyang 2010). Therefore, it can be drawn 
from the above data that wild boar's disturbance reduced coverage of summer green herbaceous species, and there are differences in response to disturbance and the speed of recovery among plant species.

\section{DISCUSSION}

The percent of the ground disturbed by wild boar during the year from April 2008 to April 2009 was $35.7 \%$ of the whole plot. It was inferred from this that the cycle of wild boar's disturbance in this area was approximately 2.8 years (Table 1). The largest area disturbed by wild boar in this study site was $564 \mathrm{~m}^{2}$. The relative frequency of the disturbed areas belong to $0-5 \mathrm{~m}^{2}, 5-100 \mathrm{~m}^{2}$, and larger than $100 \mathrm{~m}^{2}$ in these areas was $39 \%, 59 \%$ and $2 \%$, respectively (Fig. 8). Disturbance by wild boar did not occur frequently from summer to fall (Table 1). This is because wild boars prefer the evergreen needle-leaf forest which had a much more food resources such as Hymenoptera and Centipeda than deciduous broad-leaf forest in summer (Park et al. 1996, Kim et al. 1998, Pinna et al. 2007). The reasons why disturbance of the ground by wild boar occurs frequently from winter to early spring are that acorns are primarily produced in the fall, and that wild boar digs up the bulbs of E. japonicum in the winter to use as their primary source of food. Fig. 9 shows the relationship between coverage of E. japonicum investigated carefully in micro-plots in May 2005 and the percentage of disturbed area at the same micro-plots from October 2008 to April 2009. Fig. 10 illustrates the relationship between the strength of wild boar's disturbance in May 2009 and the distribution of E. japonicum measured in 2008; we observed that the ground with high concentrations of E. japonicum has a tendency to be severely disturbed by wild boar. Photo 1 was taken in April 2009 and it shows traces by wild boar left after they selectively ate bulbs of E. japonicum. The bulbs of E. japonicum distributed in the mature Q. mongolica forest at Mt. Jeombong were buried $12.0 \pm 4.0 \mathrm{~cm}(N=21)$ deep and the dried weight

Table 7. Comparison of the coverage $(\%$, mean \pm standard deviation) of the each herbaceous species showing the peak performance in summer among treatments $(P<0.05)$

\begin{tabular}{|c|c|c|c|c|}
\hline Species & & $\operatorname{CON}(N=26)$ & OW $(N=24)$ & NW $(N=24)$ \\
\hline \multirow{4}{*}{ Ainsliaea acerifolia } & Jun 2008 & $20.1 \pm 26.2^{\mathrm{a}}$ & $16.8 \pm 25.5^{\mathrm{a}}$ & $2.0 \pm 4.4^{\mathrm{b}}$ \\
\hline & Sep 2008 & $12.0 \pm 15.4^{\mathrm{a}}$ & $4.1 \pm 8.9^{\mathrm{b}}$ & $4.4 \pm 7.0^{\mathrm{b}}$ \\
\hline & Jun 2009 & $21.0 \pm 25.2^{\mathrm{a}}$ & $8.5 \pm 12.7^{\mathrm{b}}$ & $4.2 \pm 8.7^{\mathrm{b}}$ \\
\hline & Sep 2009 & $7.3 \pm 11.3^{\mathrm{a}}$ & $1.6 \pm 4.3^{\mathrm{b}}$ & $2.2 \pm 4.5^{\mathrm{ab}}$ \\
\hline \multirow{4}{*}{ Astilbe chinensis var. davidii } & Jun 2008 & $18.7 \pm 29.8^{\mathrm{a}}$ & $6.3 \pm 19.5^{\mathrm{b}}$ & $1.1 \pm 3.1^{\mathrm{b}}$ \\
\hline & Sep 2008 & $12.6 \pm 22.7^{\mathrm{a}}$ & $7.9 \pm 11.1^{\mathrm{a}}$ & $2.5 \pm 5.7^{\mathrm{a}}$ \\
\hline & Jun 2009 & $15.8 \pm 25.1^{\mathrm{a}}$ & $9.7 \pm 21.1^{\mathrm{ab}}$ & $2.1 \pm 5.6^{\mathrm{b}}$ \\
\hline & Sep 2009 & $10.8 \pm 19.9^{\mathrm{a}}$ & $3.0 \pm 4.4^{\mathrm{ab}}$ & $0.8 \pm 1.7^{\mathrm{b}}$ \\
\hline \multirow{4}{*}{ Meehania urticifolia } & Jun 2008 & $4.0 \pm 5.0^{\mathrm{a}}$ & $3.3 \pm 5.9^{\mathrm{ab}}$ & $0.9 \pm 1.8^{\mathrm{b}}$ \\
\hline & Sep 2008 & $6.8 \pm 7.6^{\mathrm{a}}$ & $7.2 \pm 6.7^{\mathrm{a}}$ & $3.8 \pm 6.2^{\mathrm{b}}$ \\
\hline & Jun 2009 & $8.5 \pm 10.2^{\mathrm{a}}$ & $5.3 \pm 7.1^{\mathrm{a}}$ & $3.8 \pm 5.2^{\mathrm{a}}$ \\
\hline & Sep 2009 & $6.8 \pm 10.3^{\mathrm{a}}$ & $3.6 \pm 3.6^{\mathrm{a}}$ & $3.5 \pm 5.3^{\mathrm{a}}$ \\
\hline \multirow{4}{*}{ Pimpinella brachycarpa } & Jun 2008 & $2.9 \pm 5.3^{\mathrm{a}}$ & $1.0 \pm 1.8^{\mathrm{ab}}$ & $0.2 \pm 0.2^{\mathrm{b}}$ \\
\hline & Sep 2008 & $7.7 \pm 8.5^{\mathrm{a}}$ & $8.5 \pm 9.8^{\mathrm{a}}$ & $7.0 \pm 8.2^{\mathrm{a}}$ \\
\hline & Jun 2009 & $3.0 \pm 3.4^{\mathrm{a}}$ & $1.0 \pm 1.7^{\mathrm{a}}$ & $1.6 \pm 3.7^{\mathrm{a}}$ \\
\hline & Sep 2009 & $2.0 \pm 3.0^{\mathrm{a}}$ & $2.1 \pm 4.3^{\mathrm{a}}$ & $0.7 \pm 1.3^{\mathrm{a}}$ \\
\hline \multirow{4}{*}{ Total coverage of herb layer (\%) } & Jun 2008 & $82.3 \pm 12.8^{\mathrm{a}}$ & $56.5 \pm 26.8^{\mathrm{b}}$ & $15.6 \pm 12.3^{\mathrm{c}}$ \\
\hline & Sep 2008 & $69.6 \pm 14.1^{\mathrm{a}}$ & $54.0 \pm 18.5^{\mathrm{b}}$ & $34.3 \pm 14.8^{\mathrm{c}}$ \\
\hline & Jun 2009 & $75.4 \pm 12.3^{\mathrm{a}}$ & $56.8 \pm 26.4^{\mathrm{b}}$ & $26.9 \pm 17.0^{c}$ \\
\hline & Sep 2009 & $54.8 \pm 21.5^{\mathrm{a}}$ & $42.9 \pm 23.5^{\mathrm{ab}}$ & $30.2 \pm 19.0^{\mathrm{b}}$ \\
\hline
\end{tabular}

CON, control; OW, old wild boar disturbed site; NW, new wild boar disturbed site. 


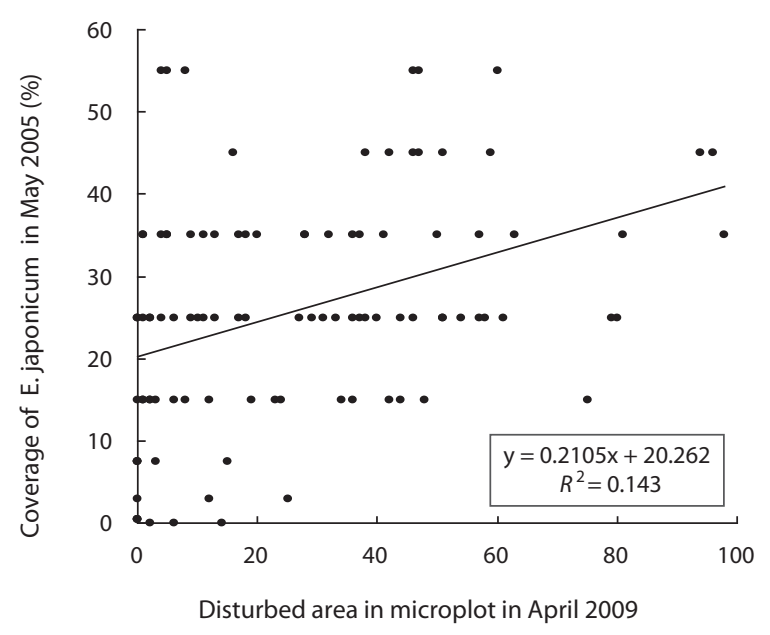

Fig. 9. Relationship between the disturbed area (\%) by wild boar investigated in April 2009 and coverage (\%) of Erythronium japonicum in May 2005 on the micro-plots.

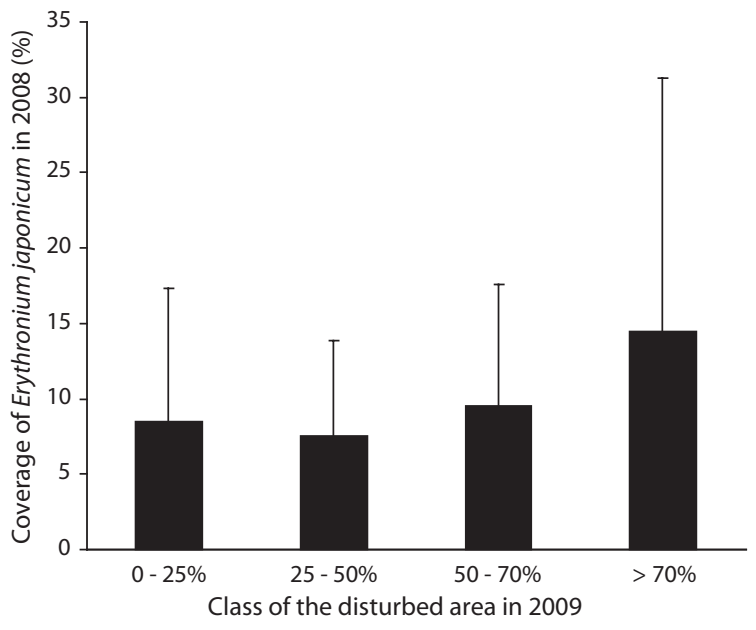

Fig. 10. Relationship between disturbance strength by wild boar on May 9, 2009 and coverage(mean \pm SD) of Erythronium japonicum investigated on May 3, 2008.

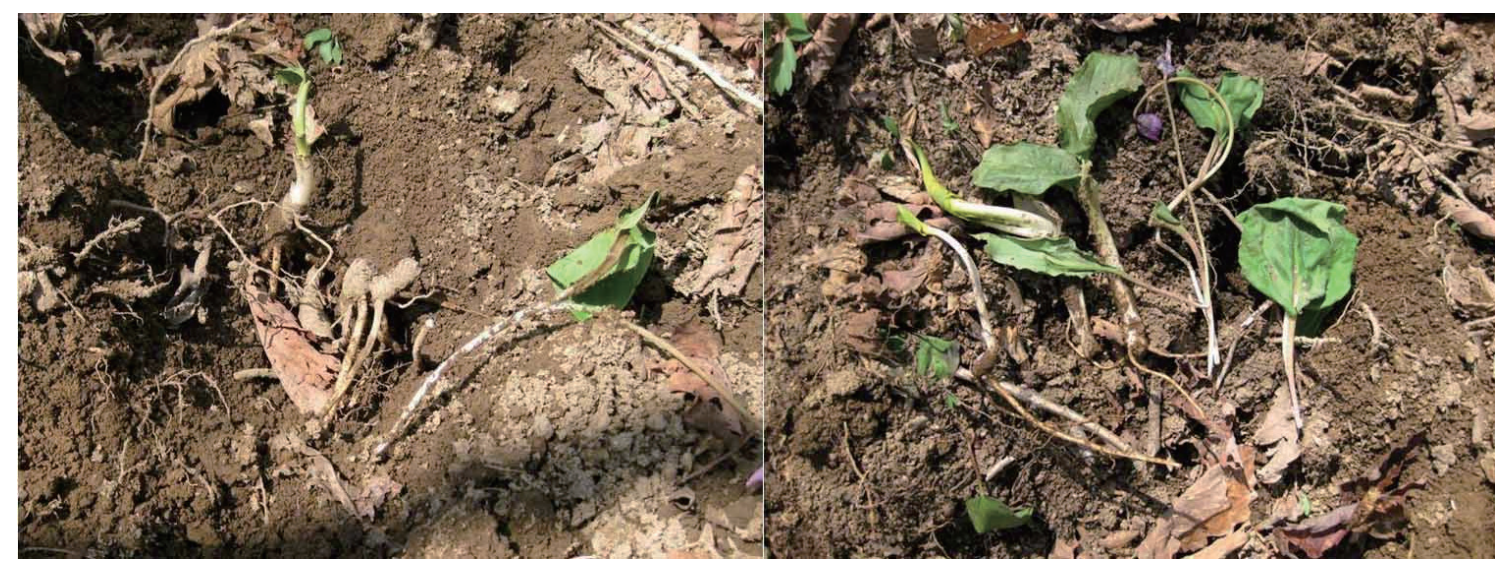

Photo 1. Scenes of disturbed traces by wild boar after the selective foraging of Erythronium japonicum bulbs on April 29, 2009.

of bulb was $0.85 \pm 0.59 \mathrm{~g}(N=21)$. These bulbs are bigger than bulbs or underground parts such as rhizome or edible roots of other herbaceous plants distributed in the investigation site. The depth of sites disturbed by wild boar $13.3 \pm 5.6 \mathrm{~cm}$. This depth is nearly identical to the depth of E. japonicum bulbs. Therefore, the wild boar's disturbance of the investigation site in early spring occurs primarily where E. japonicum is concentrated.

Relatively light disturbances by wild boar occurred in the central part of the south-facing steep slope of a permanent plot where the population density of E. japonicum was low (Figs. 11 and 12). This result corroborates the report of Seo and Park (2000) that wild boar avoids steep areas. In addition, relatively small number of disturbances by wild boar occurred in the northwest and southwest ends of the permanent plot. This is because in this area rocky outcrops are common, and E. japonicum do not well inhabit in such areas. The occurrence of wild boar's disturbance had a very strong negative correlation with coverage of naked rock ( $r=0.41, P<0.001)$ (Lyang 2010).

The physical disturbance of the ground by wild boar creates micro-topographies such as pit and mounds. It was shown that the wild boar's disturbance affects the development of the litter layer by causing differences in the thickness and coverage of the litter layer according to the micro-topography (Table 2). The litter layer of pits is the most developed and mounds are the least developed (Lee and Cho 1999). The thickness of litter layer is one of the most important environmental factors affecting species richness, species diversity, and species distribution of the herb layer in a mature oak forest at Mt. Jeombong 


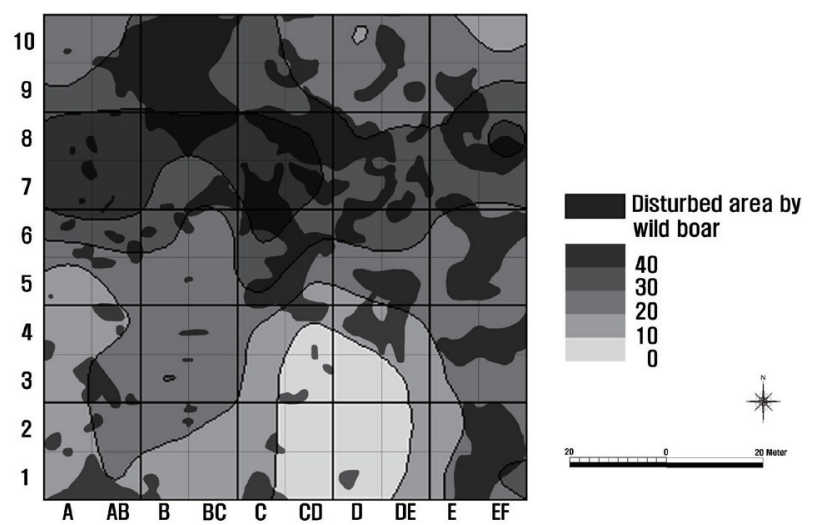

Fig. 11. Distribution of disturbed traces by wild boar from October 2008 to April 2009, and spatial distribution of the coverage (\%) of Erythronium japonicum in 2005 in the 1.0 ha permanent plot (Hong 2005).

(Lee and Cho 2000a). It was observed that the wild boar greatly contributes to the rearrangement of litter layer. Soil temperature, moisture content, organic content and nutrient content are affected by the litter layer, which is itself spatially rearranged according many factors including wind, micro-topography and concentration of shrub and trees. This irregular distribution of litter layer exerts the greatest influence on the spatial distribution of herbaceous plants in a forest (Lee and Cho 2000b).

The followings are some factors causing spatial heterogeneity of the local environment in a mature Q. mongoli$c a$ forest at Mt. Jeombong: (1) slope aspect and degree, (2) topography, (3) the rearrangement of litter layer by wind, (4) the heterogeneity of light caused by formation of gaps in a forest, (5) the distribution of rock on the ground, (6) the change of micro-topography by wild boar. The maintenance of the overall diversity and spatial distribution of wild life in a mature forest is decided by their adaptation to the changes and distribution of the light, litter, nutrients, micro-climate, slope, micro-topography caused by disturbances such as those caused by wild boar, typhoons, and more. Detailed studies on all of these factors are required to understand of the function of forest ecosystem (Kim 1997, Lee and Cho 2000a, 2000b).

In particular, wild boar's disturbance exerts a great influence on many characteristics such as the whole coverage, species richness and evenness of the herb layer (Table 3). Milton et al. (1997) reported that in Germany wild boar's disturbance reduces species richness. Characteristics of the community are greatly affected immediately after the wild boar's disturbance occurred, but these characteristics are recovered to different extents over time, reflecting the heterogeneity of the vegetation structure (Fig. 7). Each quadrat for this study was additionally

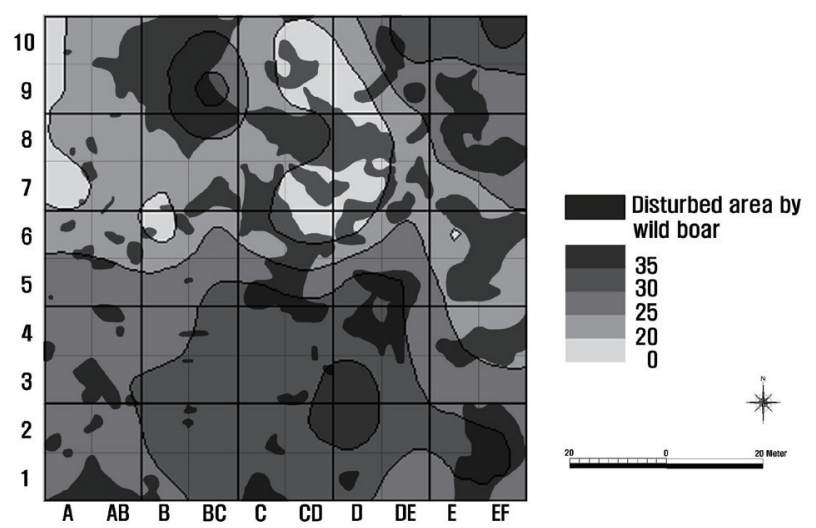

Fig. 12. Distribution of disturbed traces by wild boar from October 2008 to April 2009, and spatial distribution of slope degree $\left(^{\circ}\right)$ in the 1.0 ha permanent plot (Hong 2005).

disturbed by wild boar over time, and the additionallydisturbed area of OW and NW has a tendency to be bigger than that of CON (Table 3). This means these additionally-disturbed sites may have wild boar's preferred specific elements (e.g. the abundant distribution of wild boar's preferred plants for food) more than CON. In addition, this is related to the observation that once a place is disturbed by wild boar the place is disturbed many times (Fig. 4) (Groot Buinderink and Hazebroek 1996).

The sum of coverage of spring ephemeral on CON was significantly higher than that on OW and NW (Fig. 8). In particular, coverage of Veratrum nigrum var. ussuriense, S. niponnicus, A. koraiensis, and C. turtschaninovii was decreased by wild boar's disturbance (Table 6). Coverage of E. japonicum, the plant to which wild boar prefers, did not decrease to a statistically significant level by disturbance of wild boar (Table 6). This is because a fast recovery of the E. japonicum population is possible due to plentiful buried seed pools and asexual reproduction by division of bulbs (Lim 1993, Yoshie and Fukuda 1994, Kondo et al. 2002, Kawano 2005). Coverage of summer green herbaceous plants also decreased due to disturbance by wild boar. In particular, A. chinensis, A. acerifolia, M. urticifolia, and P. brachycarpa, which are dominant in this season, showed a decrease (Table 6). In all the quadrats disturbed by wild boar dominant plants had a tendency to be recovered over time; and so, the community structure of NW and OW developed similarly to OW and CON, respectively, after 2 years elapsed. It is predicted that the recovery to the original state following disturbance by wild boar will require more than two years (Lyang 2010).

The correlation analysis between disturbance of wild boar and herbaceous plants is essential to understand- 
ing the structure and function of the forest ecosystem. This is because wild boar's physical disturbance has been shown to directly affect herbaceous plants in forest. This research observed that wild boar's food source in early spring is the herbaceous plant E. japonicum (Figs. 9, 10, 11, and Photo 1), but it could identify why wild boar prefers to E. japonicum. Most herbaceous plants are not directly eaten by wild boar. However, they are harmed indirectly while wild boar is digging for its preferred plant $(E$. japonicum) and eating it, and the structure of community is changed. During this process, some plants are disadvantaged while others receive a new opportunity. This plays a role in increasing the diversity of the herbaceous community on a large scale (Connell 1978). Wild boar's disturbance occurs at all seasons of the year although there are differences in its intensity and scale according to season (Table 1). We could not directly observe wild boar's correct diet source during season from summer to fall. Further studies are required to learn more about the wild boar's seasonal diet. Wild boar causes disturbance in a forest through other activities including bathing, rubbing trees, and building a place to sleep in addition to the foraging activities reported here. Furthermore, concrete studies on the influences by these activities of wild boar are required to understand the structure and the function of the mature Q. mongolica forest.

\section{ACKNOWLEDGMENTS}

This research was completed with the support of the long-term ecological monitoring research (LTER) project of the Ministry of Environment. We thank Bo-Ram Hong, Hak-Joon Lee, Tae-Bok Kwak, Bong-Hoi Koo, Joo-Hoen Lee, Mi-Hee Kim, Hee-Kyeong Choi, Eun-Joo Shin, HyeYeong Kim, and Ji-Weon Kang for their assistance with data collection in the field for this research.

\section{LITERATURE CITED}

Choi TY, Choi HM. 2008. Illustration of the Traces of the Wildlife. Dolbegae, Seoul. (in Korean)

Connell JH. 1978. Diversity in tropical rain forests and coral reefs. Science 199: 1302-1310.

Gómez JM, Hódar JA. 2008. Wild boars (Sus scrofa) affect the recruitment rate and spatial distribution of holm oak (Quercus ilex). For Ecol Manage 256: 1384-1389.

Groot Buinderink GWTA, Hazebroek E. 1996. Wild boar (Sus scrofa L.) rooting and forest regeneration on podzolic soils in the Netherlands. For Ecol Manage 88: 71-80.

Hong BR. 2005. Preliminary study for the long-term ecological research of the forest vegetation in Mt. Jumbong, Korea. MS Thesis. Kangnung National University, Gangneung, Korea.

Kawano S. 2005. Life-history monographs of Japanese plants. 1: Erythronium japonicum Decne. (Liliaceae). Plant Species Biol 20: 67-78.

Kim SY. 1997. Comparison of environmental factors and herb responses between gaps and non-gaps in Mt. Jumbong. MS Thesis. The Catholic University of Korea, Bucheon, Korea.

Kim WJ, Pack CH, Kim WM. 1998. Development of habitat suitability analysis models for wild boar (Sus Scrofa): acase study of Mt. Sulak and Mt. Jumbong. J GIS Assoc Korea 6: 247-256.

Kondo T, Okubo N, Miura T, Honda K, Ishikawa Y. 2002. Ecophysiology of seed germination in Erythronium japonicum (Liliaceae) with underdeveloped embryos. Am J Bot 89: 1779-1784.

Lee KS, Cho DS. 1999. Spatial distribution of herbal vegetation along microtopographic gradients formed by disturbance in a temperate deciduous hardwood forest. Korean J Ecol 22: 211-217.

Lee KS, Cho DS. 2000a. Relationships between the spatial distribution of vegetation and microenvironment in a temperate hardwood forest in Mt. Jumbong biosphere reserve area, Korea. Korean J Ecol 23: 241-253.

Lee KS, Cho DS. 2000b. The effects of microenvironmental heterogeneity on the spatial distribution of herbaceous species in a temperate hardwood forest. Korean J Ecol 23: 255-266.

Lim SC. 1993. The study of propagating method on Erythronium japonicum DECAISNE. J Korean Soc Int Agric 5: 175-178.

Lyang DY. 2010. Effects of disturbance by wild boar (Sus scrofa coreanus Heude) on the herb layer vegetation in Quercus mongolica Forest, Mt. Jumbong, Korea. MS Thesis. Gangneung-Wonju National University, Gangneung, Korea.

Melis C, Szafranska PA, Jedrzejewska B, Barton K. 2006. Biogeographical variation in the population density of wild boar (Sus scrofa) in western Eurasia. J Biogeogr 33: 803811.

Milton SJ, Dean WR, Klotz S. 1997. Effects of small-scale animal disturbances on plant assemblages of set-aside land in central Germany. JVeg Sci 8: 45-54.

Moody A, Jones JA. 2000. Soil response to canopy position and feral pig disturbance beneath Quercus agrifolia on Santa Cruz island, Califonia. App Soil Ecol 14: 269-281. 
Park HH, Jung CE, Lee JH, Lee BY. 1996. Soil microarthropods fauna at the Namsan and Kwangreung. Korean J Soil Zool 1: 37-47.

Pielou EC. 1969. An Introduction to Mathematical Ecology. Wiely-Interscience, New York, NY.

Pinna W, Nieddu G, Moniello G, Cappai MG. 2007. Vegetable and animal food sorts found in the gastric content of Sardinian wild boar (Sus scrofa meridionalis). J Anim Physiol Anim Nutr (Berl) 91: 252-255.

Seo CW, Park CH. 2000. Wild boar (Sus scrofa coreanus Heude) habitat modeling using GIS and logistic regression. J GIS Assoc Korea 8: 85-99.
Tierney TA, Cushman JH. 2006. Temporal changes in native and exotic vegetation and soil characteristics following disturbances by feral pigs in a California grassland. Biol Invasions 8: 1073-1089.

Yoon SI. 2007. Crop loss survey by wildlife in national parks of Korea. Korean J Environ Biol 25: 223-227.

Yoshie F, Fukuda T. 1994. Effects of growth temperature and winter duration on leaf phenology of Erythronium japonicum, a forest spring geophyte. Oecologia 97: 366368. 